Gut, 1972, 13, 796-801

\title{
Circulating antibodies to cow's milk proteins in ulcerative colitis
}

\author{
From the Nuffield Department of Clinical Medicine, Radcliffe Infirmary, Oxford
}

D. P. JEWELL AND S. C. TRUELOVE

SUMmARY Sera from patients with ulcerative colitis (51), Crohn's disease (30), hypolactasia (13), untreated adult coeliac disease (11), irritable colon syndrome (24), and sera from 38 healthy control subjects were tested for antibodies to the principal cow's milk proteins-casein, $\alpha$-lactalbumin, and $\beta$-lactoglobulin. The red-cell-linked antigen-antiglobulin reaction was used to determine the titres of direct agglutinating antibodies and IgA and IgG incomplete antibodies.

Apart from patients with coeliac disease, direct agglutinating antibodies were found infrequently and then in low titres. Approximately $50 \%$ of subjects had low titres of IgA and IgG antibodies. However, the titres found in sera from patients with ulcerative colitis did not differ from those found in the control subjects or in patients with Crohn's disease, hypolactasia, or irritable colon syndrome. Patients with untreated coeliac disease frequently had high antibody titres to the milk proteins. In all subjects tested, incomplete antibodies of IgA or IgG immunoglobulin class occurred with equal frequency.

The frequent occurrence in adults of low titres of antibodies to the milk proteins may be due to continued absorption of minute amounts of protein. Absorption of allergens may be facilitated by mucosal damage, such as that of coeliac disease, with stimulation of antibody production. At the present time, however, there is little evidence to suggest that milk allergy is a factor in the aetiology of ulcerative colitis.

The finding of raised circulating antibody titres to the cow's milk proteins in patients with ulcerative colitis (Taylor and Truelove, 1961; Taylor, Truelove, and Wright, 1964) supported the earlier clinical observations that an allergy to milk proteins might be involved in the aetiology of the disease (Andresen, 1942; Rowe, 1942; Mackie, 1942; Sarles, Deck, Chalvet, and Ambrosi, 1959; Truelove, 1961). A controlled therapeutic trial of a milk-free diet showed that about $20 \%$ of patients with ulcerative colitis would benefit from milk withdrawal (Wright and Truelove, 1965a). However, when serial observations were made during the trial period on the antibody titres to the milk proteins, it was concluded that the response to a milk-free diet in an individual patient could not be predicted from the antibody titres (Wright and Truelove, 1965b). Patients with high titres to whole cow's milk were especially liable to suffer from multiple relapses but, apart from this, no correlation was found between the height of the titre and any of the important clinical features of the disease.

Received for publication 4 August 1972.
The test used in these earlier studies was the tannedred-cell haemagglutination technique. Since tannic acid alters the red cell membrane in such a way that proteins combine with the red cell non-specifically, an antiglobulin reaction cannot be employed. The red-cell-linked antigen-antiglobulin reaction (Steele and Coombs, 1964) has therefore been used in the present study in order to detect incomplete antibodies to milk proteins in the serum of patients with ulcerative colitis. The use of specific anti-immunoglobulin antisera has allowed the immunoglobulin class of these antibodies to be determined.

\section{Methods}

PATIENTS' SERA

Serum from patients with ulcerative colitis was stored in $1 \mathrm{ml}$ aliquots at $-20^{\circ} \mathrm{C}$. Sera were tested within two weeks of collection and were not thawed and refrozen more than three times. They were not heat-inactivated. Sera from patients with Crohn's disease, hypolactasia, coeliac disease, and irritable colon syndrome and from healthy subjects were also 
tested. The healthy controls had no history of milk intolerance.

\section{MILK PROTEINS}

Purified casein, $\alpha$-lactalbumin, and $\beta$-lactoglobulin were supplied by $\mathrm{Dr} R$. Lyster of the National Institute for Research in Dairying. They had been prepared by the method of Gunther, Aschaffenburg, Matthews, Parish, and Coombs (1960).

\section{ANTISERA}

Antisera to casein, $a$-lactalbumin, and $\beta$-lactoglobulin were prepared in rabbits by injecting intramuscularly $1 \mathrm{mg}$ of allergen in complete Freund's adjuvant, followed by weekly injections of allergen alone. An anti-rabbit-globulin antiserum was similarly prepared in a goat. Antisera were heat inactivated at $56^{\circ} \mathrm{C}$ for $30 \mathrm{~min}$ and $1 \mathrm{ml}$ aliquots were absorbed twice for 15 minutes each with an equal volume of fresh human group $O$ red cells which had been washed six times in phosphate-buffered saline, $p \mathrm{H} \mathrm{7 \cdot 2.}$

Antisera specific for IgA and IgG were obtained commercially (Hyland).

Antiserum to human group $O$ red cells was made in rabbits. Fresh red cells were washed three times in phosphate-buffered saline. Then $2.5 \mathrm{ml}$ of a $10 \%$ suspension was injected intraperitoneally on alternate days for five doses. The animal was bled 14 days later and the serum obtained was inactivated at $56^{\circ} \mathrm{C}$ for $30 \mathrm{~min}$. The globulin fraction of the antiserum was precipitated with $50 \%$ ammonium sulphate, washed twice in $50 \%$ ammonium sulphate solution, and finally resuspended in phosphatebuffered saline. Excess ammonium sulphate was removed by dialysis against phosphate-buffered saline. The protein content of the antiserum was estimated by the method of Lowry, Rosebrough, Farr, and Randall (1951). A protein concentration of approximately $5 \mathrm{mg} / \mathrm{ml}$ was obtained by ultracentrifugation.

\section{PHOTO-OXIDIZATION}

The individual milk proteins were coupled to the antihuman group $\mathrm{O}$ red cell antiserum by the process of photo-oxidization (Steele and Coombs, 1964).
Two $\mathrm{ml}$ of antiserum and $2 \mathrm{ml}$ of a solution of allergen, containing about $5 \mathrm{mg}$ of protein $/ \mathrm{ml}$, were placed in a $50 \mathrm{ml}$ conical flask: $0.2 \mathrm{ml}$ of Rose Bengal $(1 \%)$ was added and the flasks were gently shaken on a mechanical shaker under bright illumination. The process was continued until conjugation had taken place, as determined serologically, and this usually occurred between 13 and 16 hours. To test for adequate coupling, the conjugates were serially diluted to 1 in 512 in $0.2 \mathrm{ml}$ volumes. Five drops of $4 \%$ fresh human group $O$ red cells (washed three times in phosphate-buffered saline) were added to each tube and allowed to incubate in the dark for one hour. The sensitized cells were washed twice and then added to (1) normal rabbit serum (absorbed twice with group $O$ red cells, heat inactivated) $1 / 500$; (2) anti-allergen antiserum 1 in 100 and 1 in 500; (3) goat anti-rabbit-globulin antiserum 1/200. Satisfactory conjugation of the allergen to the antired-cell antibody was judged by $(a)$ the absence of direct agglutinating activity of the anti-red-cell serum and $(b)$ agglutination to a high titre with antiallergen and anti-rabbit globulin antibody (Table I).

\section{RED-CELL-LINKED, ANTIGEN-ANTIGLOBULIN REACTION}

The conjugates of the milk proteins, prepared by photo-oxidization, were used at a 1 in 10 dilution. Two $\mathrm{ml}$ of each $(0.2 \mathrm{ml}$ conjugate $+2.0 \mathrm{ml}$ phosphate-buffered saline) was incubated at room temperature for one hour with $2 \mathrm{ml}$ of $4 \%$ fresh human group $\mathrm{O}$ red cells (washed three times in phosphate-buffered saline). The sensitized cells were washed twice in phosphate-buffered saline and resuspended to $2 \%$. Five drops of sensitized cells were then added to $0.2 \mathrm{ml}$ of patient's sera, which had been serially diluted to 1 in 512, and incubated for a further hour. The cells were washed twice in normal rabbit serum (heat inactivated, absorbed twice with group $O$ red cells and used at a dilution of 1/500). One drop of resuspended cells was then added to 1 drop of: (1) normal rabbit serum $1 / 500$, (2) antiIgA antiserum, 1/100, (3) anti-IgG antiserum, 1/500. Agglutination was read after one to one and a half hours. The presence of direct agglutinating antibody in patient's sera was shown by agglutina-

\begin{tabular}{|c|c|c|c|c|c|c|c|c|c|c|}
\hline & 2 & 4 & 8 & 16 & 32 & 64 & 128 & 256 & 512 & $S A L$ \\
\hline \multicolumn{11}{|l|}{ Normal rabbit serum } \\
\hline Anti-a-lactalbumin $1 / 100$ & $\bar{t}+$ & $\bar{t}+$ & $\bar{t}+$ & $\overrightarrow{+}+$ & $\bar{t}+$ & $\bar{t}+$ & $\overline{+}$ & $\overline{+}$ & - & $\overline{-}$ \\
\hline $1 / 500$ & + & + & + & - & - & - & - & - & - & - \\
\hline Goat anti-rabbit $1 / 200$ & ++ & ++ & $+t$ & $+t$ & $+t$ & $+t$ & ++ & ++ & + & - \\
\hline
\end{tabular}

Table I Serological testing for adequate conjugation of a-lactalbumin to anti-red cell antibody by photo-oxidation for 15 hours 
tion observed in normal rabbit serum, whereas incomplete IgA or IgG antibodies were detected by agglutination in the presence of the anti-immunoglobulin antisera.

\section{Results}

Sera from 51 patients with ulcerative colitis were compared with healthy control subjects (38) and with patients suffering from Crohn's disease (30), hypolactasia (13), irritable colon syndrome (24), and coeliac disease (11). The age and sex distribution of these patients is shown in Tables II and III. Duplicate

\begin{tabular}{lccl}
\hline Diagnosis & $<30$ & $30-60$ & $>60$ \\
& Years & Years & Years \\
\hline Ulcerative colitis & 12 & 32 & 7 \\
Crohn's disease & 13 & 14 & 3 \\
Hypolactasia & 3 & 9 & 1 \\
Coeliac disease & 3 & 6 & 2 \\
Normals & 24 & 10 & 4 \\
Irritable colon syndrome & 4 & 16 & 4 \\
\hline
\end{tabular}

Table II Age distribution of patients and controls

\begin{tabular}{lccc}
\hline Diagnosis & Males & Females & Total \\
\hline Ulcerative colitis & 18 & 33 & 51 \\
Crohn's disease & 21 & 9 & 30 \\
Hypolactasia & 6 & 7 & 13 \\
Coeliac disease & 4 & 7 & 11 \\
Normals & 7 & 31 & 38 \\
Irritable colon syndrome & 7 & 17 & 24 \\
\hline
\end{tabular}

Table III Sex distribution of patients and controls

observations were not routinely made on each serum but, when they were made, the results did not differ by more than one titre.

The antibody titres obtained in each diagnostic category are represented as histograms shown in Figures 1-3.

Direct agglutinating antibodies to casein, $a$ lactalbumin, and $\beta$-lactoglobulin were found in only a small minority of patients and then in low titres. This was so in all the groups of patients studied except for patients with coeliac disease who frequently had direct agglutinating antibodies to each of the three proteins, often in high titres.

Sera from patients with coeliac disease also frequently contained high titres of $\operatorname{IgA}$ and IgG anti-
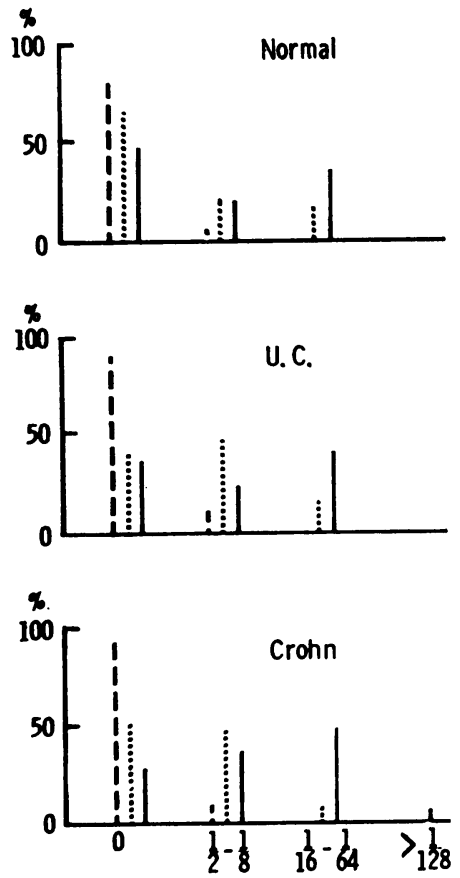
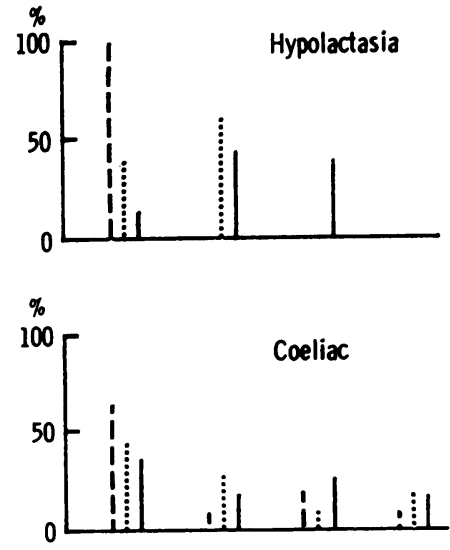

Fig. 1 Circulating antibody titres to casein

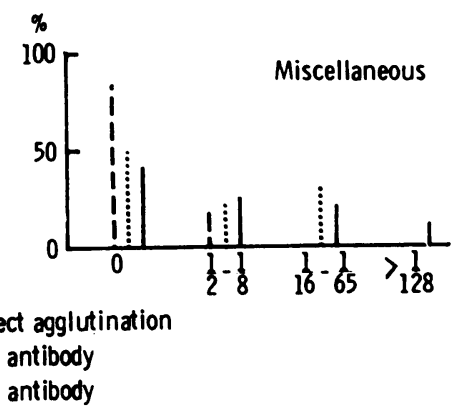



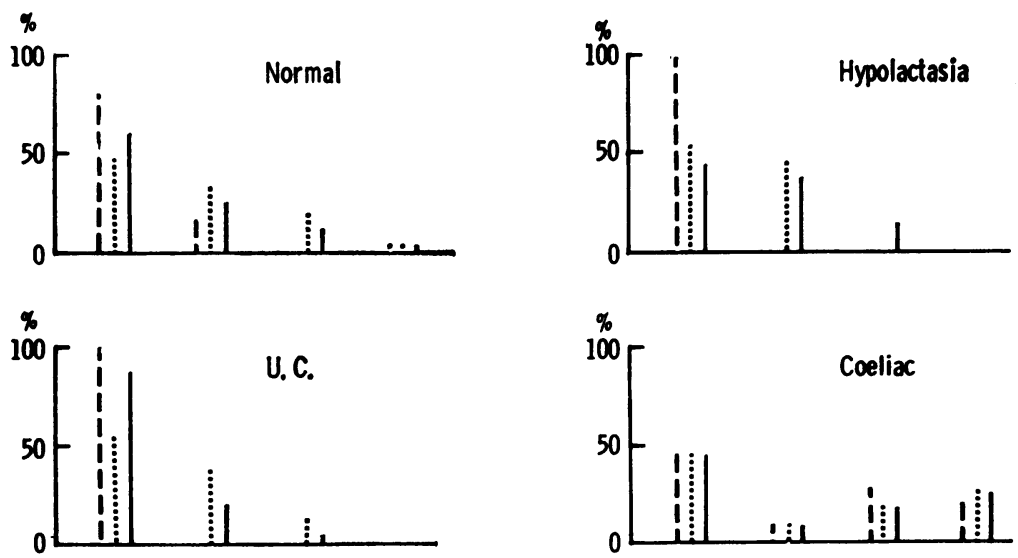

Fig. 2 Circulating antibody to a-lactalbumin
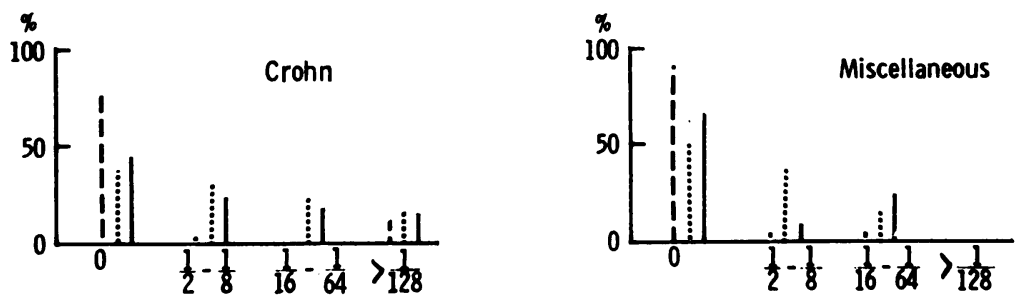

- - - Direct agglutination

IgA antibody

IgG antibody
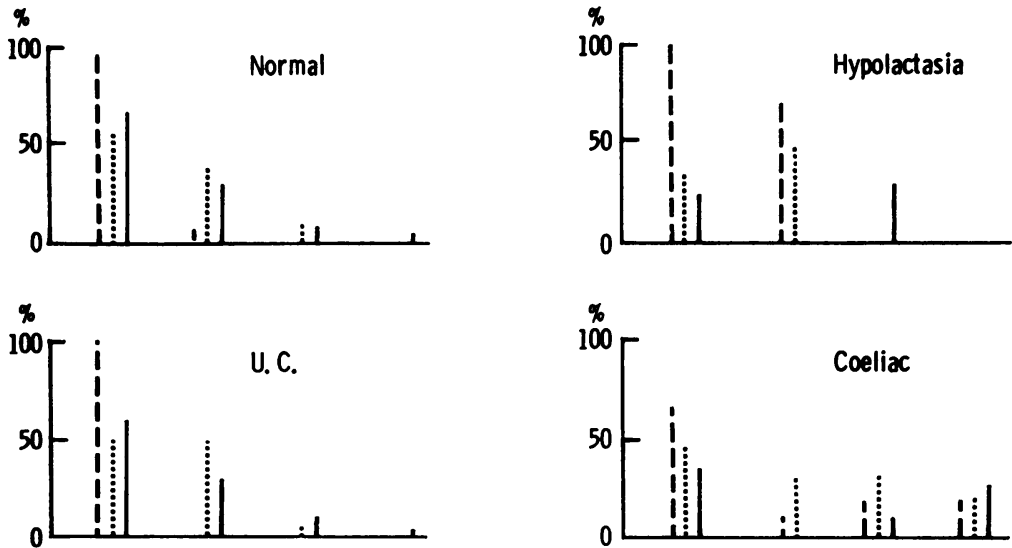

Fig. 3 Circulating antibody titres to $\beta$-lactoglobulin
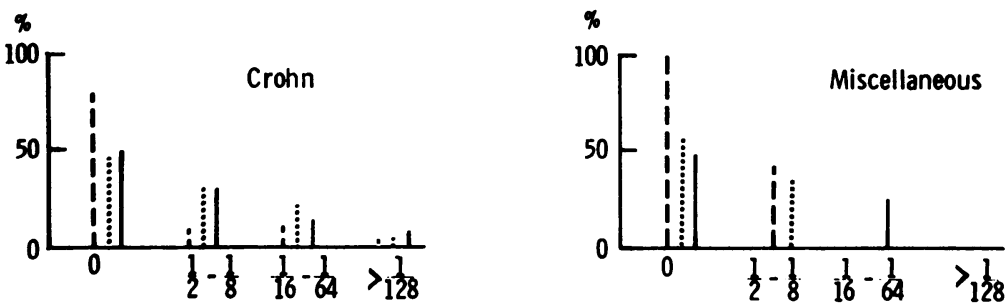

. - Direct agglutination

IgA antibody

IgG antibody 
bodies to each of the three proteins. In the other diagnostic groups, low titres were present in approximately $50 \%$ of subjects but there were no striking differences between them. Patients with ulcerative colitis did not differ from the control groups either in the frequency with which antibodies occurred or in the height of the titres demonstrated. Low titres of both IgA and IgG antibodies were especially frequent in patients with hypolactasia. Patients with Crohn's disease tended to have somewhat higher titres to $\alpha$-lactalbumin and $\beta$-lactoglobulin than the control subjects.

The antibody titres obtained in sera from patients with ulcerative colitis or Crohn's disease were analysed in relation to the clinical features of the two diseases. No correlation was found between the antibody titre and the length of history, severity or extent of the disease, or corticosteroid therapy.

The height of the titres of direct or indirect IgA or IgG antibodies to the individual milk proteins was also analysed in relation to the results obtained with intradermal testing (Jewell and Truelove, 1972). The only correlation found was that patients with positive skin tests to casein were more likely to have direct agglutinating antibodies in their sera.

In each of the diagnostic categories, the frequency of antibodies of IgA immunoglobulin class was closely similar to that of IgG antibodies. This applied to each of the three milk proteins.

Three patients with irritable colon syndrome had high IgG antibody titres (1 in 512) to casein. One patient had relief of symptoms with a milk-free diet and relapsed when challenged with either pure casein or whole milk. The second had no improvement with a milk-free diet and the third, similarly, had no improvement in bowel symptoms but found that aphthous ulcers rapidly healed. The aphthous ulceration recurred when milk was re-introduced into her diet but healed again on withdrawing milk. All three patients had strongly positive skin tests to casein.

\section{Discussion}

No difference has been found between the sera from patients with ulcerative colitis and sera from healthy control subjects with respect to antibody titres to the three milk proteins. This applies to the direct agglutinating antibodies as well as to the incomplete IgA and IgG antibodies. This confirms the negative results of some earlier reports (Sewell, Cooke, Cox, and Meynell, 1963; Dudek, Spiro, and Thayer, 1965) but is in contrast to the raised titres found in ulcerative colitis by Taylor and Truelove (1961) and Taylor et al (1964). When the titres found in sera from patients with ulcerative colitis or Crohn's disease in the present study were analysed in relation to length of history, extent and severity of disease, and corticosteroid therapy, no correlation was found.

The discrepancy between the results of Taylor and his colleagues and the present results may be due to differences in method. The earlier studies employed tanned-red-cell haemagglutination as opposed to the red-cell-linked antigen-antiglobulin reaction. No attempt was made to compare the two methods, but Steele and Coombs (1964) have found that there is a poor correlation between the two haemagglutination tests. The linked antigen test often gave significant titres when the tanned cell test failed to demonstrate antibody. This is probably due to the fact that incomplete antibodies are hardly detected, if at all, by the tanned cell test. Similarly the tanned cell test often gave high titres when the direct agglutination titre of the linked antigen test was lower. Three possible explanations were advanced, namely, (1) the tanned cell may be coated with more antigen per unit surface area; (2) the tanned cell is less stable as it is very 'sticky' and therefore very sensitive; (3) in the linked antigen test, the antigen may be slightly denatured by photo-oxidization.

Another possible explanation for the discrepant results depends on the frequency of liver disease in the patients studied. Triger, Alp, and Wright (1972) have shown that patients with liver disease have higher antibody titres to dietary allergens than patients without liver disease. The proportion of patients with ulcerative colitis or Crohn's disease who had liver disease in the present study was very small and it is therefore possible that the results of Taylor and his colleagues may have been biased by a higher proportion of patients with liver disease included in their series.

The frequency with which circulating antibodies are found in serum probably reflects the absorption of whole protein molecules from the intestine. As far as milk proteins are concerned the absorption of minute amounts of unaltered protein has been shown to occur in children (Ratner and Gruehl, 1934; Lippard, Schloss, and Johnson, 1936). It has also been shown that antibody titres to cow's milk proteins are higher in infants than in adults, especially in infants who have received cow's milk within the first week or two of life (Gunther et al, 1960; Gunther, Cheek, Matthews, and Coombs, 1962). Another indication that healthy individuals are commonly sensitized to the milk proteins is the high frequency of positive skin reactions to these proteins observed in normal subjects (Jewell and Truelove, 1972), although it is presumed that anaphylaxis is prevented by other mechanisms such as the presence of blocking antibody.

When the small-intestinal mucosa is damaged, as 
in coeliac disease, it is possible that absorption of protein molecules may be facilitated. This might provide an explanation for the finding of high titres of antibodies to the milk proteins in patients with coeliac disease both in this study and in other reported series (Sewell et al, 1963; Taylor et al, 1964; Kenrick and Walker-Smith, 1970; Ferguson and Carswell, 1972). As coeliac patients have antibodies to a variety of dietary antigens, it seems likely that these occur secondary to mucosal damage with increased absorption and are not of prime aetiological significance.

There are at least two possible reasons why the absorption of whole protein molecules may be increased in Crohn's disease and ulcerative colitis: (1) minor villous abnormalities of the jejunal mucosa are common in both these diseases (Salem, Truelove, and Richards, 1964); (2) an appreciable proportion of digested dietary protein is undigested by the time the terminal ileum is reached (Borgström, Dahlqvist, Lundh, and Sjövall, 1957) and it is therefore liable to come into contact with the inflamed mucosa.

There is, therefore, little evidence to support the hypothesis that an allergy to milk proteins is an aetiological factor in ulcerative colitis. No evidence of a reaginic response to milk has been obtained (Jewell and Truelove, 1972) and the present results show that circulating IgA, IgG, or direct agglutinating antibodies are found no more frequently in patients with ulcerative colitis than in control subjects. Using a delayed skin reaction as an indicator of a cellular immune response, no evidence has been found for a cell-mediated hypersensitivity to the milk proteins (Jewell, 1972).

The clinical benefits of a milk-free diet in ulcerative colitis may depend on factors other than immunological ones. Cady, Rhodes, Littman, and Crane (1967) found an increased frequency of hypolactasia in ulcerative colitis but a detailed study by Pena and Truelove (1972) showed that only patients with a severe attack of the disease had a significantly higher frequency of hypolactasia when compared with controls. In the majority of patients, hypolactasia persisted following treatment of the attack and it was postulated that patients with ulcerative colitis who also have an isolated lactase deficiency are more prone than the other patients with the disease to suffer from attacks and for these attacks to become severe.
References

Andresen, A. F. R. (1942). Ulcerative colitis-an allergic phenomenon. Amer. J. dig. Dis., 9, 91-97.

Borgström, B., Dahlqvist, A., Lundh, G., and Sjövall, J. (1957). Studies of intestinal digestion and absorption in the human. J. clin. Invest., 36, 1521-1536.

Cady, A. B., Rhodes, J. B., Littman, A., and Crane, R. K. (1967). Significance of lactase deficit in ulcerative colitis. J. Lab. clin. Med., 70, 279-286.

Dudek, B., Spiro, H. M., and Thayer, W. R., Jr, (1965). A study of ulcerative colitis and circulating antibodies to milk proteins. Gastroenterology, 49, 544-547.

Ferguson, A., and Carswell, F. (1972). Precipitins to dietary proteins in serum and upper intestinal secretions of coeliac children. Brit. med. J., 1, 75-77.

Gunther, M., Aschaffenburg, R., Matthews, R. H., Parish, W. E., and Coombs, R. R. A. (1960). The level of antibodies to the proteins of cow's milk in the serum of normal human infants. Immunology, 3, 296-306.

Gunther, M., Cheek, E., Matthews, R. H., and Coombs, R. R. A. (1962). Immune responses in infants to cow's milk proteins taken by mouth. Int. Arch. Allergy, 21, 257-278.

Jewell, D. P. (1972). Immunological studies in ulcerative colitis and Crohn's disease. D. Phil. Thesis, Oxford University.

Jewell, D. P., and Truelove, S. C. (1972). Reaginic hypersensitivity in ulcerative colitis. Gut, in press.

Kenrick, K. G., and Walker-Smith, J. A. (1970). Immunoglobulins and dietary protein antibodies in childhood coeliac disease. Gut, 11, 635-640.

Lippard, V. W., Schloss, O. M., and Johnson, A. P. (1936). Immune reactions induced in infants by intestinal absorption of incompletely digested cow's milk protein. Amer. J. Dis. Child., 51, 562-574.

Lowry, O. H., Rosebrough, N. J., Farr, A. L., and Randall, R. J. (1951). Protein measurement with the folin phenol reagent. $J$. biol. Chem., 193, 265-275.

Mackie, T. T. (1942). Discussion to Andressen (1942). Ulcerative colitis-an allergic phenomenon. Amer. J. dig. Dis., 9, 97.

Pena, A. S., and Truelove, S. C. (1972). Hypolactasia and ulcerative colitis. Gastroenterology, in press.

Ratner, B., and Gruehl, H. L. (1934). Passage of native proteins through the normal gastro-intestinal wall. J. clin. Invest. $13,517-532$.

Rowe, A. H. (1942). Chronic ulcerative colitis-allergy in its etiology. Ann. intern. Med., 17, 83-100.

Salem, S. N., Truelove, S. C., and Richards, W. C. D. (1964). Small intestinal and gastric changes in ulcerative colitis: a biopsy study. Brit. med. J., 1, 394-398.

Sarles, H., Deck, M., Chalvet, H., and Ambrosi, L. (1959). Rectocolite hémorragique et allergie alimentaire. Arch. Mal. Appar. dig., 48, 907-925.

Sewell, P., Cooke, W. T., Cox, E. V., and Meynell, M. J. (1963). Milk intolerance in gastrointestinal disorders. Lancet, 2, 1132-1135.

Steele, A. S. V., and Coombs, R. R. A. (1964). The red cell linked antigen test for incomplete antibodies to soluble proteins. Int. Arch. Allergy, 25, 11-25.

Taylor, K. B., and Truelove, S. C. (1961). Circulating antibodies to milk proteins in ulcerative colitis. Brit. med. J., 2, 924-929.

Taylor, K. B., Truelove, S. C., and Wright, R. (1964). Serologic reactions to gluten and cow's milk proteins in gastro-intestinal disease. Gastroenterology, 46, 99-108.

Triger, D. R., Alp, M. H., and Wright, R. (1972). Bacterial and dietary antibodies in liver disease. Lancet, 60-63.

Truelove, S. C. (1961). Ulcerative colitis provoked by milk. Brit. med. J., 1, 154-160.

Wright, R., and Truelove, S. C. (1965a). A controlled therapeutic trial of various diets in ulcerative colitis. Brit. med. J., 2, 138141.

Wright, R., and Truelove, S. C. (1965b). Circulating antibodies to dietary proteins in ulcerative colitis. Brit. med. J., 2, 142-144. 